Review

\title{
National and International Standardization (International Organization for Standardization and European Committee for Standardization) Relevant for Sustainability in Construction
}

Guri Krigsvoll ${ }^{1}$, Marina Fumo ${ }^{2}$ and Renata Morbiducci ${ }^{3}{ }^{3}$

1 Faculty of Engineering, Oslo University College, Pilestredet 35, 0130 Oslo, Norway;

E-Mail: guri.krigsvoll@iu.hio.no

2 Dipartimento di Progettazione Urbana e di Urbanistica, Università degli Studi di Napoli Federico II, via Forno Vecchio, 36, 80134, Napoli, Italy; E-Mail: mfumo@unina.it

3 Department of Science for Architecture (DSA), University of Genoa, Stradone S.Agostino 37, 16123, Genova, Italy

* Author to whom correspondence should be addressed; E-Mail: renata.morbiducci@ unige.it; Tel.: +39-0103532942; Fax: +39-0103532534.

Received: 5 November 2010; in revised form: 23 November 2010 / Accepted: 15 December 2010 / Published: 20 December 2010

\begin{abstract}
Sustainability in construction has a short history in terms of principles, standardizations and applications. From the Brundtland Report "Our Common Future", a new vision of the resource deficits, climate impacts and the social responsibility gave growth to the idea of sustainability also in design and construction. Consequently, in around 2000, the international and national organizations for standardization started to develop standards for the application of sustainable principles. This paper gives an overview of existing and planned standards, and examples on how to use them as a framework for the development of methods and tools for assessment.
\end{abstract}

Keywords: sustainability in construction; international and national standardization; standards as framework for assessment 


\section{Introduction}

The International Organization for Standardization (ISO) wrote in an overview of its system: "If there were no standards, we would soon notice. Standards make an enormous contribution to most aspects of our lives, although very often, that contribution is invisible. It is when there is an absence of standards that their importance is brought home. For example, as purchasers or users of products, we soon notice when they turn out to be of poor quality, do not fit, are incompatible with equipment we already have, are unreliable or dangerous. When products meet our expectations, we tend to take this for granted. We are usually unaware of the role played by standards in raising levels of quality, safety, reliability, efficiency and interchangeability, as well as in providing such benefits at an economical cost". This explanation of what would happen if standards did not exist is useful to understand the why of this work.

Sustainability and, in particular, sustainability in construction, has a short developing history in terms of principles, standardizations and applications. Since the Report of the World Commission on Environment and Development: Our Common Future [1], in which the concept of sustainable development was coined (by Brundtland, the Prime Minister of Norway), the term "sustainability" has been used more and more in many fields, from the industry to the common people. The focus on environmental aspects in the construction field has increased in an exponential manner from when, for instance, the reports of the United Nations Framework Convention on Climate Change (UNFCCC) showed that almost one-third of bear energy is used for constructions and from when the Kyoto Protocol was written.

This new vision of need for more sustainable products, design and construction processes were noticed by the international, and consequently, national organizations for standardization and these organizations started to analyze and develop new standards for the application of sustainable principles in the field of construction. The basic idea of the standardization work for sustainability in this field is that all construction works must fulfill functional and technical performance requirements, but additionally they have to consider the environmental, social and economic performances. An important issue is that every product or element involved in a construction work has to be considered in the assessment of those performances. Thus, the standardizations for production, transport, building process, use and end of life have to be considered together.

While the challenge of sustainable development is global, the strategies for addressing sustainability in building construction are essentially local and differ in context and content from region to region. Thus, these strategies will reflect the context, the preconditions and the priorities and needs, not only in the built environment, but also in the social environment. In particular, the social environment includes social equity, cultural issues, traditions, heritage issues, human health and comfort, social infrastructure and safe and healthy environments. In developing countries in particular, the social environment may include poverty reduction, job creation, access to safe, affordable and healthy shelter and loss of livelihoods. 


\section{National and International Standardization Work Related to Sustainability}

Observing the work of the Technical Commissions of the ISO, it is possible to point out some reports that analyze and then develop singularly standards in those sectors linked with the sustainability in construction concept (for instance): ISO/TC43 (Acoustics), ISO/TC59 (Building Construction), ISO/TC146 (Air quality), ISO/TC163 (Thermal performance and energy use in the built environment), ISO/TC205 (Building environment design), etc. In a very similar manner, the European Committee for Standardization (CEN) examines and establishes standards for the same sectors, many time following the ISO Standards, for instance, CEN/TC89 (Thermal performance of buildings), CEN/TC126 (Acoustic properties of building elements and of buildings), CEN/TC156 (Ventilation for buildings), CEN/TC 169 (Energy performance of buildings), CEN/TC350 (Sustainability of construction works), CEN/TC351 Construction products-Assessment of release of dangerous substances, CEN/TC371 Energy Performance of Building project group, etc. Finally the national standardization body may use the international standard as the national standard; sometimes the standards are translated and fit for the national characteristics (for instance the Italian UNI EN 12354 [2] and UNI TR 11175:2005 [3] - Building acoustics), and in other cases the international standard is translated exactly (for instance the Italian UNI EN ISO 13788:2003-Hygrothermal performance of building components and building elements [4]).

In particular, the ISO/TC207 (Environmental Management) was established in 1993 with the scope of "standardization in the field of environmental management tools and systems". This Technical Commission does not set limits or performance criteria for operations or products; instead, its activities are based on the philosophy that improving management practices is the best way to improve the environmental performance of organizations and their products. SC3 (Environmental labels and declarations) is the subcommittee that establishes guiding principles for the development and use of environmental labels and declarations (the ISO 14020-21-24-25 [5-8]), while SC5 (Environmental management-Life Cycle Assessment) is the sub-committee that established standards for the applications of LCA methods (the ISO 14040 [9], 14044 [10], 14047 [11], 14048 [12] and 14049 [13]). Recently, due to the climate change discussion, SC7 (Green house gas management and related activities) was established. This sub-committee (SC) has the responsibility for the development of standards like ISO/WD 14067-1 Carbon footprint of products-Part 1: Quantification and ISO/WD 14067-2 Carbon footprint of products-Part 2: Communication (these documents only exist as internal reports, and as such they are not referable).

Another important event was in June 2007, when the ISO Technical Management Board (TMB) decided to establish a task force of TMB Members with the charge to develop an appropriate channel of communication with the ISO Committees on standards and sustainability, to carry out an inventory of ISO work relevant to sustainability, and to propose terms of reference for a possible Strategic Advisory Group (SAG). This resolution was based on the fact that sustainability is not the exclusive domain of any one ISO TC or activity, but in fact all ISO's work program contributes in some manner to sustainability.

Using the term of sustainability, the building industry was forced to not only think of energy efficient buildings or good indoor environments, but also to have other aspects in mind. For construction as such, sustainability still is regarded as equivalent to environmental efficient or "green". 
ISO/TC59/SC17 (Building construction-Sustainability in building construction) is the first ISO committee addressing sustainability in its work, but many already existing standards, and standards under preparation, have considerable influence on the work, as standards in the field of environmental management (ISO 14000), environmental life cycle assessment [9], environmental declaration [14] and international standards on service life planning (ISO 15686 series). This sub-committee is developing specific series of standards for building construction [15-19].

In Europe the main important Technical Committee for the sustainability in construction field is probably the European CEN/TC350 (Sustainability of construction works). It is aiming at the development of voluntary horizontal standardized methods for the assessment of the sustainability aspects of new and existing construction works and for standards for the environmental product declaration of construction products as part of implementation of European policy. This Technical Committee points out that the Life Cycle Analysis is considered one of the best tools, because it examines the full range of impacts over all the phases of a building's useful life, instead of focusing on any particular stage [20].

The previous section presented a brief description of the state of art of the current standard situation for sustainability in construction. In the next sections, some more detailed information will be discussed about this field in terms of principles and their practical applications (Table 1).

Table 1. The International Standards: Published and under development/revision by ISO and the CEN organization; documents related to environment management and sustainability of construction.

\begin{tabular}{|c|c|c|c|c|}
\hline \multicolumn{3}{|c|}{ Published } & \multicolumn{2}{c|}{ Under Development/Revision } \\
\hline \multicolumn{2}{|c|}{ ISO } & CEN & ISO & CEN \\
\hline $\begin{array}{c}\text { Related to } \\
\text { Manvironment }\end{array}$ & $\begin{array}{c}\text { Related to } \\
\text { Sustainability } \\
\text { of Construction }\end{array}$ & $\begin{array}{c}\text { Related to } \\
\text { Sustainability of } \\
\text { Construction }\end{array}$ & $\begin{array}{c}\text { Related to } \\
\text { Sustainability of } \\
\text { Construction }\end{array}$ & $\begin{array}{c}\text { Related to } \\
\text { Sustainability of } \\
\text { Construction }\end{array}$ \\
\hline 14040 & $15392 / 08$ & EN 15643-1 & $15686-1 / 00$ & FprEN 15643-2 \\
\hline 14025 & TS 21929-1/06 & CEN/TR 15941 & $15686-2 / 02$ & prEN 15643-3 \\
\hline 14044 & $21930 / 07$ & & $15686-3 / 02$ & prEN 15643-4 \\
\hline & TS 21931-1/06 & & $15686-5 / 08$ & prEN 15978 \\
\hline & & & $15686-6 / 07$ & FprEN 15942 \\
\hline & & & $15686-7 / 06$ & \\
\hline & & & $15686-8 / 08$ & \\
\hline & & & $15686-10 / 10$ & \\
\hline & & & DTR 21932 & \\
\hline & & & TS 21929/06 & \\
\hline & & & TS 21930/07 & \\
\hline & & & NP TS 12720 & \\
\hline & & & & \\
\hline & & & & \\
\hline
\end{tabular}




\section{The Published International Standards Related to Environment Management}

The International Standards Organization has worked with many countries and organizations to bring the 14000 standards forward for the world as a whole, considering that "A set of international standards brings a worldwide focus to the environment, encouraging a cleaner, safer, healthier world for us all". Moreover, these standards were created to give countries at least a minimum environmental standard to aim for. Within the ISO, TC207 has responsibility for the development of environmental management standards, including those dealing with life cycle assessment (LCA). In particular, some recent changes have been made to the ISO norms that standardize the methodology for LCA, for process or service over the course of its entire life cycle. It has come a long way since the 1960s where its roots took shape as the result of the need for energy optimization within industry.

The first "multi-criteria" study was carried out by Coca-Cola around 1969. The process was further developed at a SETAC conference in Vermont in 1990, which included inventory, interpretation and improvement.

In 1998, ISO standardized the methodology with the publication of the first version of ISO 14040, (14041 - Goal and Scope Definition and Inventory Analysis) and in 2000 (14042 - Life Cycle Impact Assessment, 14043-Life Cycle Interpretation). These are the standards that have been revised, cancelled and replaced by the publication of ISO 14040:2006 [9] outlining LCA principles and framework and ISO 14044:2006 [10] for requirements and guidelines. These ISO LCA standards have established a worldwide set of rules to ensure that LCA studies are conducted in a consistent, reproducible fashion. The standards define what should be considered in setting the goal and scope of the study, what data are needed, how to evaluate the quality of the data, what impact assessment categories will be used (and why), how the results can be interpreted for improvement, what information should be included, and when different levels of review are necessary [21]. Another published international standard is the ISO 14025 [14]. This is the environmental declaration providing quantified environmental data using predetermined parameters and, where relevant, additional environmental information (the predetermined parameters are based on the ISO 14040 LCA series of standards which is made up of ISO 14040 [9] and ISO 14044 [10]; the additional environmental information may be quantitative or qualitative).

\section{The Published International Standards Related to Sustainability of Construction}

\subsection{ISO/TC59/SC17 "Sustainability in Building Construction"}

ISO/TC59/SC17 "Sustainability in building construction" was established in 2002 as a result of preliminary work conducted since 1999 by WG12 on Sustainability in ISO/TC59/SC3 "Functional/user requirements and performance in building construction". For the past 10 years, substantial work on international standardization related to sustainability in building construction has been undertaken within ISO/TC59's SC3 and SC17, based on the formative work and international activities in the International Council for Research and Innovation in Building and Construction (CIB).

SC17 is working to develop a suite of standards covering all aspects related to sustainability in building construction. The SC17 consists of both Participating Members (that come from 20 nations) and Observer Members (that come from 10 nations). The main field of the standardization is the 
sustainability of the built environment; in particular environmental, economic, and social aspects of sustainability are included as appropriate. The ISO/TC59/SC17 has the following structure:

- WG 1 "General principles and terminology"

- WG 2 "Sustainability indicators"

- WG 3 "Environmental declarations of products"

- WG 4 "Environmental performance of buildings"

- WG 5 "Civil engineering works"

SC 17 has published:

- $\quad$ ISO 15392:2008 [15]

- ISO/TS 21929-1:2006 [16]

- $\quad$ ISO 21930:2007 [17]

- $\quad$ ISO/TS 21931-1:2006 [18]

These technical specifications and other work items in SC17 are described in the next chapter.

\section{The International Standards under Development or Revision Related to Sustainability of Construction}

The standardization process should be a consensus-building and a participatory process. ISO standards relate to other standards, while CEN standards relate to directives or policies (i.e., the ECOLABEL, a voluntary scheme established in 1992 to encourage businesses to market products and services that are kinder to the environment). An important issue is to harmonize existing approaches and to be performance based rather than prescriptive.

\subsection{The European Ecolabel}

The European Ecolabel is a voluntary scheme, established in 1992 to encourage businesses to market products and services that are kinder to the environment. Products and services awarded the Ecolabel show the flower logo to identify them easily. Today the EU Ecolabel covers a wide range of products and services, with further groups being continuously added. Product groups include many fields among which there is a group that is studying the development of the European Ecolabel criteria for buildings. From several previous analyses carried out by the Building group for the development of the European Ecolabel criteria, the prevalence in terms of market data, existing certified buildings, existing certification schemes in place, of the residential building sector, has emerged. The product group definition for "buildings" shall comprise: "buildings considered in their entirety, as well as small houses, new or existing, public or private, used for residential purpose and for use as offices". New buildings include also major refurbishments. Existing buildings include also renovations. Residential purpose is meant as for dwelling purpose. Use as offices is meant to be the use of the building for administrative, bureaucratic and educational activities of a public or private nature. 


\subsection{ISO/TC59/SC17 "Sustainability on Building Construction"}

The WGs in SC17 have to develop standards according to the work program that foresee the "General principles" [22-30], Terminology [19], Framework for the development of indicators for buildings [16], Environmental declaration of building products [17], and Framework for methods of assessment for environmental performance of construction works-Part 1 [18]. In the next part, the main detailed news about the AWI (Approved Work Item) and the different CDs (Committee Draft) will be discussed.

Taking into account that ongoing standardization work is covering buildings (SC under TC59 Building construction) a new work item, Development of a framework for sustainable indicators for civil engineering works/infrastructures, was approved in October 2007.

\subsubsection{ISO 15392 Sustainability in Building Construction—General Principle}

This standard identifies and establishes general principles for sustainability. It is based on the concept of sustainable development as it applies to buildings and other construction works, from their inception to the end of life, understood as their "life cycle". The standard is applicable to buildings and constructions individually and collectively, as well as to the materials, products, services and processes related to the life cycle of construction.

The standard is not intended to provide the basis for assessment of organizations or other stake-holders, and does not provide levels (benchmarks) that can serve as the basis for sustainability claims. The principles established in this standard are intended to be applied broadly in the context of construction. Specific applications are the subject of other related international standards. Buildings are designed to meet numerous requirements, expressed and established in national and international standards or regulations. None of these requirements is replaced or changed by this standard.

To increase the implementation of this standard, a technical specification, ISO/NP TS 12720 Sustainability in building construction-Guidelines for the application of the general principles on sustainability, is under development.

\subsubsection{ISO/TR 21932 Sustainability in Building Construction-Terminology}

This Technical Report gives the terminology used in the suite of standards.

\subsubsection{ISO/TS 21929-1 Sustainability in Building Construction—Sustainability Indicators}

- Part 1: Framework for the development of indicators for buildings

ISO/TS 21929-1 provides a framework, makes recommendations, and gives guidelines for the development and selection of appropriate sustainability indicators for buildings. The aim of this part of ISO/TS 21929 is to define the process that shall be followed when addressing the economic, environmental and social impacts of a building using a common framework and a set of indicators. In particular the ISO/TS 21929-1: 
- $\quad$ adapts general sustainability principles for buildings

- includes a framework for the assessment of economic, environmental and social impacts of buildings

- $\quad$ shows indicators as examples

- $\quad$ shows how to use sustainability indicators with regard to buildings and shows the process of using sustainability indicators

- $\quad$ supports the process of choosing indicators

- $\quad$ supports the development of assessment tools

- defines the conformity with this specification.

The work toward developing this TS to an approved standard is ongoing, giving a standard that provides a framework for the development of sustainability indicators for buildings, including a list of core indicators which define the environmental, economic and social aspects of buildings for assessing their contribution to sustainable development. The object of consideration is a building or a group of buildings and the external works within the site (curtilage).

\subsubsection{ISO 21930 Sustainability in Building Construction-Environmental Declaration of Building} Products

ISO 21930 provides the principles and requirements for Type III environmental declarations of building products. It gives guidelines for the development and implementation of such declarations based on the Life Cycle Assessment. The standard contains specifications and requirements for the environmental product declaration (EPD) of building products. Where this standard contains more specific requirements, it complements ISO/FDIS 14025 [9] for the EPD of building products.

ISO 21930 provides a framework for and basic requirements for Product Category Rules (PCR), as defined in ISO/FDIS 14025 for Type III environmental declarations of building products. Type III environmental declarations for building products as described here are primarily intended for use in business to business communication, but their use in business to consumer communication under certain conditions is not precluded. The standard does not define the requirements for developing Type III environmental declarations. This kind of requirement declaration program is found in the ISO/FDIS 14025.

The working environment is not included in this ISO 21930 because it is normally a subject for national legislation.

In the practice of developing Type III environmental declarations, the program or its declarations are referred to by various names such as Eco-Leaf, eco-profile, environmental declaration of product, environmental product declaration (EPD), environmental profile, etc.

\subsubsection{ISO/TS 21931-1 Sustainability in Building Construction-Framework for Methods of} Assessment for Environmental Performance of Construction Works-Part 1: Framework for Development of Indicators for Buildings

ISO/TS 21931-1 provides a general framework for improving the quality and comparability of methods for assessing the environmental performance of buildings. It identifies and describes issues to 
be taken into account when using methods for the assessment of environmental performance for new or existing building properties in the design, construction, operation, refurbishment and deconstruction stages. This TS is undergoing the process of further development to the standard ISO 21931-1 Sustainability in building construction-Framework for methods of assessment for environmental performance of construction works-Part 1: Buildings

The building is the object of the assessment defined in this part of ISO/TS 21931, and this encompasses the building itself, the site and the associated facilities on the site. It is recognized that environmental performance is only one of a number of significant factors in a building's overall performance.

This part of ISO 21931 [18] is intended be used in conjunction with, and follow the principles set out in, the ISO 14000 series of International Standards.

\subsection{CEN TC350 "Sustainability of Construction Works"}

The TC350 shall be responsible for the development of voluntary horizontal standardized methods for the assessment of the sustainability aspects of new and existing construction works and for standards for the environmental product declaration of construction products. The standards will be generally applicable (horizontal) and relevant for the assessment of integrated performance of buildings over their life cycle. The standards will describe a harmonized methodology for assessment of the environmental performance of buildings and life cycle cost performance of buildings as well as the quantifiable performance aspects of health and comfort of buildings.

In order to assess the integrated performance of buildings, it is necessary to regard a building as a whole with required performance and functions to fulfill. Consequently, during its life cycle from raw material supply of building products to the final disposal of building components, a building has environmental and economic impacts as well as impacts on the health and comfort of the users. To obtain an overall picture on the integrated performance of a building, these impacts must be analyzed with the building as an object of the assessment of environmental performance, economic performance, as well as the health and comfort performance of building.

The standards of the TC350 will provide the means for the quantification of the impacts of the Construction Industry and for understanding the results of its decisions. The standards will provide essential elements in a strategy leading to the mitigation, e.g., avoidance of climate change through understanding the effects of decisions taken in the Construction Industry. The first TC350 standards are made available in 2010, and the suite of standards will be finalized in a few years, and hence create a set of horizontal European standards in this field.

\subsubsection{WI 00350001 Sustainability of Construction Works-Framework for Assessment of Integrated Buildings Performance_-Part 1: Environment, Health and Comfort and Life Cycle Cost Performances}

This work will provide the general principles and requirements for the methodologies for the assessment of environmental performance, life cycle cost performance and health and comfort performance of buildings. The standards will be generally applicable (horizontal) and relevant for the assessment of the integrated performance of buildings over their entire life cycle. The standard defines the system boundaries for the assessment of the integrated performance of buildings in terms of its 
quantifiable impacts. This standard also provides the core indicators for the assessment of environmental performance, life cycle cost performance, and health and comfort performance of buildings and describes how they are treated in the overall assessment.

The following standard is published:

- EN 15643-1 Sustainability of Construction Works-Assessment of Buildings Part 1 [31].

The following standards are under approval:

- prEN 15643-2 Sustainability of Construction Works-Assessment of Buildings Part 2 [32].

- prEN 15643-3 Sustainability of Construction Works-Assessment of Buildings Part 3 [33].

- prEN 15643-4 Sustainability of Construction Works-Assessment of Buildings Part 4 [34].

5.3.2. WI00350002 Sustainability of Construction Works-Assessment of Environmental Performance of Buildings - Calculation Methods

The standard will provide a framework for calculation methods applicable to all buildings and methodology for the assessment of the environmental performances of a building. This assessment is mainly based on the result of the LCA for each of the environmental aspects over the life cycle of the building in the framework of the integrated performance of buildings. The standard describes the calculation methods for environmental core indicators defined in the framework standard according to the type of the building and various stages of the building life cycle. The standard describes the system boundaries for LCA and the European rules for LCA outcome for each aspect in order to allow for aggregation, and describes the assessment of data quality for LCA-data and the effect of data quality on the results of the LCA.

The object of the assessment is the building itself, including its foundations and external works within the area of building site, and the source of impacts over its life cycle. The physical and temporal system boundary for the assessment shall be defined in the goals of the assessment. The physical system boundary for the assessment shall exclude impacts of non-building related appliances. Non-building related appliances are domestic, commercial and industrial appliances and other non-building related goods, e.g., entertainment electronics, washing machines, refrigerators, cooking appliances, office electronics and appliances of industrial processes. Assessment of the building shall be presented with a focus on different stage of the life cycle of the building (i.e., construction stage, operation stage and end of life). The standard describes:

- The calculation methods for environmental core indicators defined in the framework standard according to the type of the building and various stages of the building life cycle.

- The system boundaries for LCA and the European rules for LCA outcome for each aspect in order to allow for aggregation.

- The assessment of data quality for LCA-data and the effect of data-quality on the results of the LCA for buildings.

The calculation method should be in accordance to ISO/TS 21931-1.

The standard prEN 15978 [35] is under approval. 


\subsubsection{WI00350003 Sustainability of Construction Works - Use of Environmental Product Declarations}

This standard is applicable to cradle to grave as well as modular environmental product declarations (EPD) of building products, processes and services. It describes the requirements placed on any EPD when it is to be applied in combination with other EPDs for the assessment of the environmental performance and health and comfort performance of a building in the framework of the integrated performance of buildings. This standard gives the rules for converting the product, process or service related information, from an EPD supplying the information as related to the performance in the building. The information includes environmental and health and comfort aspects. The conversion will take account of the need to avoid data gaps, data overlaps and double counting. It also includes checking consistency, completeness and comparability as well as equivalence in quality of applied data derived from different EPD.

\subsubsection{WI00350004 Sustainability of Construction Works-Environmental Product Declarations- Product Category Rules for Construction Products}

This standard is applicable to building products, processes and services. The product category rules specify requirements for all building products in accordance with ISO 21930 [17] and ISO 14025 [14] for the intended audience, whether business or consumers. This standard supports the application of environmental product declarations for the assessment of the environmental performance of buildings and for the assessment of the health and comfort performance of buildings in the framework of the integrated performance of buildings.

\subsubsection{WI00350005 Sustainability of Construction Works-Environmental Product Declarations- Communication Formats}

This standard is applicable to all building products, processes and services. It defines and describes the communication formats of an environmental product declaration dependent on the intended audience; business or consumers. FprEN 15942 [36] is under approval.

5.3.6. WI00350006 Sustainability of Construction Works_Environmental Product DeclarationsMethodology and Data for Generic Data

This technical report describes the sources and methodology to be used when preparing generic data for environmental product declarations. The methodology complies with the requirements of ISO 14044 [10]. The report supports the development of the product category rules for environmental declarations of building products, processes and services addressing the use of generic data. CEN/TR 15941 [37] was published in 2010.

\subsubsection{WI 00350007 Sustainability of Construction Works - Description of the Building Life Cycle}

This technical report is meant to describe the building life cycle within the framework standard. In order to complement other work items, this technical report focuses on processes and scenarios related 
to the building life cycle, and describes items such as service life, technical performance and performance requirements. This technical report expressly serves the demands of that framework standard rather than being a standalone document on the description of the building life cycle. This work item is not started, but awaiting decisions from the EC and CEN.

\section{Conclusions}

The ongoing international standardization work related to sustainability in construction will make assessments of the sustainability aspects of new and existing construction works more transparent and the results more comparable than what is possible with today's methods. Standards for the environmental product declaration of construction products will make it easier for actors to decide which products, but also which systems, to use in construction.

An increased interest for using the standards, and the information given according to the standards, will aid in more sustainable constructions. The described standards will give companies a reliable business environment and enable the exchange of sustainability information related to internationally traded products and services.

\section{Acknowledgements}

The authors are grateful to the COST (the Intergovernmental Framework for European Cooperation in Science and Technology) for its contribution to allowing the development of the action COST-25 (Sustainability of Constructions: Integrated Approach to Life-time Structural Engineering) in which the present work was carried out.

\section{References and Notes}

1. Our Common Future: The World Commission on Environment and Development; Oxford University Press: Oxford, UK, 1987.

2. UNI EN 12354:2002 Building Acoustics-Estimation of Acoustic Performance of Buildings from the Performance of Elements-Airborne Sound Insulation between Rooms.

3. UNI TR 11175:2005 Building Acoustics-Guideline to the Standards UNI EN 12354 for the estimate of the Acoustic Performance of Buildings-Application to the National Building Types.

4. UNI EN ISO 13788:2003 Hygrothermal Performance of Building Components and Building Elements-Internal Surface Temperature to Avoid Critical Surface Humidity and Interstitial Condensation-Calculation Methods.

5. ISO 14020:2000 Environmental Labels and Declarations-General Principles; International Organization for Standardization: Geneva, Switzerland, 2000.

6. ISO 14021:1999 Environmental Labels and Declarations-Self-Declared Environmental Claims (Type II Environmental Labelling); International Organization for Standardization: Geneva, Switzerland, 1999. 
7. ISO 14024:1999 Environmental Labels and Declarations-Type I Environmental LabellingPrinciples and Procedures; International Organization for Standardization: Geneva, Switzerland, 1999.

8. ISO 14025:2006 Environmental Labels and Declarations-Type III Environmental Declarations-Principles and Procedures; International Organization for Standardization: Geneva, Switzerland, 2006.

9. ISO 14040:2006 Environmental Management-Life Cycle Assessment-Principles and Framework; International Organization for Standardization: Geneva, Switzerland, 2006.

10. ISO 14044:2006 Environmental Management-Life Cycle Assessment-Requirements and Guidelines; International Organization for Standardization: Geneva, Switzerland, 2006.

11. ISO/TR 14047:2003 Environmental Management-Life Cycle Impact Assessment-Examples of Application of ISO 14042; International Organization for Standardization: Geneva, Switzerland, 2003.

12. ISO/TS 14048:2002 Environmental Management_Life Cycle Assessment_Data Documentation Format; International Organization for Standardization: Geneva, Switzerland, 2002.

13. ISO/TR 14049:2000 Environmental Management-Life Cycle Assessment-Examples of Application of ISO 14041 to Goal and Scope Definition and Inventory Analysis; International Organization for Standardization: Geneva, Switzerland, 2000.

14. ISO 14025:2006 Environmental Labels and Declarations-Type III Environmental Declarations-Principles and Procedures; International Organization for Standardization: Geneva, Switzerland, 2006.

15. ISO 15392:2008 Building Construction-Sustainability in Building Construction-General Principles; International Organization for Standardization: Geneva, Switzerland, 2008.

16. ISO/TS 21929-1:2006 Building Construction-Sustainability in Building ConstructionSustainability Indicators-Part 1-Framework for Development of Indicators for Buildings; International Organization for Standardization: Geneva, Switzerland, 2006.

17. ISO 21930:2007 Building Construction-Sustainability in Building Construction-Environmental Declaration of Building Products; International Organization for Standardization: Geneva, Switzerland, 2007.

18. ISO/TS 21931-1:2010 Building Construction-Sustainability in Building ConstructionFramework for Methods of Assessment for Environmental Performance of Construction WorksPart 1-Buildings; International Organization for Standardization: Geneva, Switzerland, 2010.

19. ISO/DTR 21932 Building Construction-Sustainability in Building Construction-Terminology; International Organization for Standardization: Geneva, Switzerland, 2010.

20. Life-Cycle Assessment in Building and Construction: A State-Of-The-Art Report of Setac Europe; Kotaji, S., Schuurmans, A., Edwards, S., Eds.; Setac-Europe: Brussels, Belgium, 2003.

21. Fava, J.A. Can ISO life cycle assessment standards provide credibility for LCA? Build. Des. Construct. 2005, 11, 17-20.

22. ISO 15686-1:2000 Buildings and Constructed Assets-Service Life Planning-Part 1: General Principles; International Organization for Standardization: Geneva, Switzerland, 2000. 
23. ISO 15686-2:2001 Buildings and Constructed Assets-Service Life Planning-Part 2: Service Life Prediction Procedures; International Organization for Standardization: Geneva, Switzerland, 2001.

24. ISO 15686-3:2002 Buildings and Constructed Assets-Service Life Planning-Part 3: Performance Audits and Reviews; International Organization for Standardization: Geneva, Switzerland, 2002.

25. ISO 15686-5:2008 Buildings and Constructed Assets-Service-Life Planning-Part 5: Life-Cycle Costing; International Organization for Standardization: Geneva, Switzerland, 2008.

26. ISO 15686-6:2004 Buildings and Constructed Assets-Service Life Planning-Part 6: Procedures for Considering Environmental Impacts; International Organization for Standardization: Geneva, Switzerland, 2004.

27. ISO 15686-7:2006 Buildings and Constructed Assets-Service Life Planning-Part 7: Performance Evaluation for Feedback of Service Life Data from Practice; International Organization for Standardization: Geneva, Switzerland, 2006.

28. ISO 15686-8:2008 Buildings and Constructed Assets-Service-Life Planning-Part 8: Reference Service Life and service-life Estimation; International Organization for Standardization: Geneva, Switzerland, 2008.

29. ISO/TS 15686-9:2008 Buildings and Constructed Assets-Service-Life Planning-Part 9: Guidance on Assessment of Service-Life Data; International Organization for Standardization: Geneva, Switzerland, 2008.

30. ISO 15686-10:2010 Buildings and Constructed Assets-Service Life Planning-Part 10: When to Assess Functional Performance; International Organization for Standardization: Geneva, Switzerland, 2010.

31. EN 15643-1: 2010 Sustainability of Construction Works-Assessment of Buildings Part 1: General Framework; European Committee for Standardization: Brussels, Belgium, 2010.

32. FprEN 15643-2: 2011-03 Sustainability of Construction Works-Assessment of Buildings Part 2: Framework for the Assessment of Environmental Performance; European Committee for Standardization: Brussels, Belgium, 2011.

33. prEN 15643-3: 2012-01 Sustainability of Construction Works-Assessment of Buildings_Part 3: Framework for the Assessment of Social Performance; European Committee for Standardization: Brussels, Belgium, 2012.

34. prEN 15643-4: 2012-01 Sustainability of Construction Works-Assessment of Buildings-Part 4: Framework for the assessment of economic performance; European Committee for Standardization: Brussels, Belgium, 2012.

35. prEN 15978: 2012-02 Sustainability of Construction Works-Assessment of Environmental Performance of Buildings-Calculation Method; European Committee for Standardization: Brussels, Belgium, 2012.

36. FprEN 15942: 2011-02 Sustainability of Construction Works-Environmental Product Declarations-Communication Format-Business to Business; European Committee for Standardization: Brussels, Belgium, 2011. 
37. CEN/TR 15941: 2010 Sustainability of Construction Works-Environmental Product Declarations-Methodology and Data for Generic Data; European Committee for Standardization: Brussels, Belgium, 2010.

(C) 2010 by the authors; licensee MDPI, Basel, Switzerland. This article is an open access article distributed under the terms and conditions of the Creative Commons Attribution license (http://creativecommons.org/licenses/by/3.0/). 